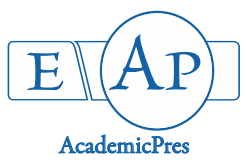

Winarto B et al. (2021)

Notulae Scientia Biologicae

Volume 13, Issue 2, Article number 10859

DOI: $10.15835 / \mathrm{nsb} 13210856$

Research Article

\title{
Growth-yield performances and partial economic analysis of sugarcane under different planting methods
}

\author{
Budi HARTOYO ${ }^{1}$, HARWANTO², Forita D. ARIANTI ${ }^{1}$, Sri \\ MINARSIH ${ }^{1}$, Raden H. PRAPTANA ${ }^{1}$, Budi WINARTO ${ }^{3 *}$ \\ ${ }^{1}$ Central Java Assessment Institute for Agriculture Technology, Jl. Soekarno Hatta KM.26 No.10, Kotak Pos 124, Bergas, Semarang, \\ 50552,CentralJava,Indonesia; budyh4r@gmail.com;dforita@yahoo.com; sriminarsih95@gmail.com; herujuly@yahoo.com \\ ${ }^{2}$ Indonesian Citrus and Subtropical Fruits Research Institute, JI. Raya Tlekung No.1, Kec. Junrejo, Kota Baru 65327, East Java, \\ Indonesia; h_harwanto@yahoo.com \\ ${ }^{3}$ Ungaran Instalation for Research and Assessment on Agriculture Technology, JI. BPTP No. 40, Bukit Tegalepek, Sidomulyo, \\ Ungaran Timur, Semarang 50514, Central Java, Indonesia; budi_winarto67@yahoo.com (*corresponding author)
}

\begin{abstract}
Sugarcane (Saccharum spp.) is an important tropical crop around the world, involving in Indonesia, however low productivity is still problem for it. The study was aimed to investigate effect of different planting methods on improving cane growth-yield performances and their partial economic analysis. The study was conducted at Gedangdowo, Jepon, Blora District, Central Java, Indonesia from 2015-2017 at initial planting (IP) to sugarcane ratoon SR-1 and SR-2. Material used was qualified seeds of PS.862 variety. Three planting methods were tested: 1) double trench system (DTS) with $50 \mathrm{~cm}$ distance between trench and $135 \mathrm{~cm}$ distance between double trenches; 2) single trench system (STS) with $120 \mathrm{~cm}$ distance of canter to center (CTC) and 3) STS with $110 \mathrm{~cm}$ distance of CTC. The experiment was arranged in randomized complete block design (RCBD) with 6 replications. Results of the study revealed that DTS 50/135 was the most appropriate planting method inducing higher cane productivity up to $129.12 \mathrm{t} /$ ha in IP, then increased up to $134.1 \mathrm{t} / \mathrm{ha}$ in SR-1 and declined down to $114.1 \mathrm{t} / \mathrm{ha}$ in SR-2. Percentage of cane productivity in DTS 50/135 increased up to $40.8 \%$ in IP, 51.1\% in SR-1 and 64.6\% in SR-2. Higher R/C ratio up to 1.99 and 1.94 was performed by STS 120 followed by DTS 50/135. Increasing R/C ratio noted in STS 120 and DTS 50/135 was 18.3 and 21.3\%, respectively on SR-1 compared to STS 110. The planting method can be applied to improve sugarcane productivity and its $\mathrm{R} / \mathrm{C}$ ratio for other varieties.
\end{abstract}

Keywords: economic analysis; growth; planting method; sugarcane; yield

\section{Introduction}

Sugarcane (Saccharum spp.) is one of important tropical crops around the world. The crop is important mainly due to the production of sugar and alcohol (Casaroli et al., 2019) and a great energy production capacity due to the burning of its dry matter (De Silva et al., 2019). In Indonesia, the sugarcane is also one of important crop estates after palm oil, rubber, coconut, coffee, cocoa, and cashew. The plants were widely developed and cultivated in several provinces with East Java, Lampung and Central Java as the main sugarcane areas (Zuraina

Received: 29 Nov 2020. Received in revised form: 10 May 2021. Accepted: 24 May 2021. Published online: 27 May 2021. From Volume 13, Issue 1, 2021, Notulae Scientia Biologicae journal uses article numbers in place of the traditional method of continuous pagination through the volume. The journal will continue to appear quarterly, as before, with four annual numbers. 
et al., 2018; Directorate General of Estate, 2020a). Total harvest areas of sugarcane were 458,432 ha; 2.4 million tons of total production and 5.5 t/ha its productivity in 2020 (Zuraina et al., 2018; Directorate General of Estate, 2020b, c). Revenue/Cost (R/C) ratio of the sugarcane agribusiness was between 1.10 to 2.9 (Hajar et al., 2019; Pokharel et al., 2019; Zaky et al., 2019). Sugar as the main product were sold from Rp. 12,000 20,000-/ $\mathrm{kg}$ (Society Relation Department, 2020). The information gives evident that sugarcane is important and has high economical estate plants in Indonesia, however development of the plant in commercial scales was constrained by low plant productivity.

In Indonesia, sugarcane productivity was still low and generally under its variety potential. On farm site, sugarcane productivity in Indonesia was only $68.29 \mathrm{t} / \mathrm{ha}$ in 2017 (Zuraina et al., 2018). The productivity decreased down to $52.2 \mathrm{t} / \mathrm{ha}$ in 2020 (Indonesian Trading Ministry, 2020). The productivity was lower than other sugarcane production countries as Brazil and China with 74.37 and $79.68 \mathrm{t} / \mathrm{ha}$, respectively. While in off farm site, sugarcane yield was only 7.50\% and lower than in Philippine, Thailand and Australia with 9.20, 10.70 and $14.12 \%$, respectively. To increase sugarcane productivity in Indonesia, several strategies were carried out such as optimizing cultivation by utilizing qualified seeds, productive varieties, optimizing land processing, managing planting system, seedling embroidering, fertilizing and root managing (Diana et al., 2016; Kadarwati, 2019; Sudarto et al., 2020); source-sink approaching (Cholid, 2013); applying organic matter and land synthetic moisturizer (Tando, 2017). The such strategies, in fact, were also done in other countries to increase sugarcane productivity (Srivastava and Rai, 2012; Bikila et al., 2014; Bokthiar et al., 2015; Lemos dos Santos et al., 2018; Singh et al., 2019). While improving sugarcane productivity under treatment of planting method published internationally is still few.

Planting method is one of important aspects that can be carried out to increase sugarcane growth and yield performances. The method is closely related to (1) seed sizes such as bud chips (Mishra, 2019), single bud seeds (Muttaqin et al., 2016; Ngatinem et al., 2019) and long stalk with several buds (Majid, 2014; Prem et al., 2017) and (2) planting system viz, single and double trenches with varied sizes (Majid, 2014; Gulati et al., 2015; Djumali et al., 2016). The bud chips were successfully applied to increase sugarcane yield up to $37.3 \%$ than conventional method (Mishra, 2019); single bud seeds with $140 \times 30 \mathrm{~cm}$ improved the highest sugarcane productivity up to $36.7 \%$ compared to other treatments (Ngatinem et al., 2019); and the long stalk in $1.8 \mathrm{~m}$ planted in narrow row of $1.25 \mathrm{~m}$ successfully increased sugarcane stalk number and its productivity up to $49.4 \%$ compared to other sizes (Majid, 2014). Furthermore, small pit method of planting $(120 \times 60 \mathrm{~cm}$ spacing with 3 settlings per pit) increased productivity up to $16.2 \%$ compared to conventional one $(15 \mathrm{~cm}$ width $15 \mathrm{~cm}$ depth with 12 settlings per pit) of planting (Gulati et al., 2015). Paired row trench plantation stimulated slightly improvement of sugarcane productivity up to $6.4 \%$ compared to conventional planting (Prem et al., 2017). Trench planting method with $120 \mathrm{~cm}$ increased sugarcane yield up to $55.2 \%$ and better than other methods (Nadeem et al., 2020). In Indonesia, double trench system (DTS) for improving sugarcane growth and yield performances was established since 2012 (Hendayana et al., 2014), however transfer and adoption of the technology in farmer level was still low. To improve interest and attractiveness of farmers to the DTS, frequent researches dealing with application of the technology nearby farmer location and partial economic analysis are importantly addressed.

New and reliable research results derived from exploring the DTS on sugarcane growth and yield performances and its farming economic analysis were successfully revealed. New findings of the research were discussed in detail in the paper.

\section{Materials and Methods}

Study site

Field experiment was carried out on 3 ha farmer land at Gedangdowo village, Japon Subdistrict, Blora District, Central Java-Indonesia on $\pm 103 \mathrm{~m}$ altitude above see level, $6^{\circ} 56^{\prime} 55.3^{\prime \prime}$ in South latitute, $111^{\circ} 27^{\prime} 46.5^{\prime \prime}$ 
in East longitute at inceptisol soil type from September 2014 to August 2017. Number of raindays in 2015 was $0-22$ days per month and 8.8 days in average with $0-176 \mathrm{~mm}$ rainfalls per month and $64.2 \mathrm{~mm}$ in average (Blora Statistic, 2015); 0-11 days and 5.6 days in average with $0-317 \mathrm{~mm}$ and $122.8 \mathrm{~mm}$ in 2016 (Blora Statistic, 2016); 2-20 days and 8.8 days with $12-410 \mathrm{~mm}$ and $146.3 \mathrm{~mm}$ (Blora Statistic, 2017). Materials used in the study were qualified seeds of PS. 862 cane variety, Phonska compound fertilizer, ZA, manure, insecticides with carbofuran as active ingredient, and fungicide. Hand tractor, sprayer, caliper, stick meter, refractometer and other supporting tools were used in the experiment.

\section{Experiment preparation}

Cane cultivation lands were prepared by soil tilling using hand tractor for four times with different purposes. First and second soil tilling was aimed to reverse soil ground $25 \mathrm{~cm}$ in depth and to clean land from rests of other vegatations that can inhibit sugarcane growth vegetatively. After the second soil tilling, the lands were harrowed to make soil become friable and finally the land plottings were settled based on planting methods tested.

Basic fertilizer, i.e. 5 tons/ha of organic manures was applied during soil harrowing. Fertilizing during in the initial planting was carried out using Phonska, ZA and organic manure and applied 4 weeks after planting (WAP) and $12 \mathrm{WAP}$. Phonska in $600 \mathrm{~kg} / \mathrm{ha}, 400 \mathrm{~kg} / \mathrm{ha}$ and $5 \mathrm{t} / \mathrm{ha}$ organic manure were applied for double trench system (DTS) with $50 \mathrm{~cm}$ distance between trench and $135 \mathrm{~cm}$ distance between double trenches; 550 $\mathrm{kg} / \mathrm{ha}$ Phonska, $350 \mathrm{~kg} / \mathrm{ha} \mathrm{Za}$ and $5 \mathrm{t} / \mathrm{ha}$ for single trench system (STS) with $120 \mathrm{~cm}$ distance of canter to center (CTC) and $500 \mathrm{~kg} / \mathrm{ha}$ Phonska, $350 \mathrm{~kg} / \mathrm{ha} \mathrm{Za}$ and $2.5 \mathrm{t} / \mathrm{ha}$ for STS with $110 \mathrm{~cm}$ distance of CTC. The fertilizers were applied by preparing long trench $10 \mathrm{~cm}$ distance from bottom stalk parts following plant trench length. The fertilizers were poured in the long trench prepared equally then covered again using soil nearby the trench.

Fertilizing at the first and second sugarcane ratoon (SR-1) was carried out using similar fertilizers and ZA and applied 1 month after ratoon (MAR) and 3 MAR. Phonska in $600 \mathrm{~kg} / \mathrm{ha}, 400 \mathrm{~kg} / \mathrm{ha}$ and $5 \mathrm{t} / \mathrm{ha}$ organic manure were applied for DTS 50/135; $550 \mathrm{~kg} / \mathrm{ha}$ Phonska, $350 \mathrm{~kg} / \mathrm{ha} \mathrm{Za}$ and $5 \mathrm{t} / \mathrm{ha}$ for STS 120 and 500 $\mathrm{kg} / \mathrm{ha}$ Phonska, $350 \mathrm{~kg} / \mathrm{ha} \mathrm{Za}$ and $2.5 \mathrm{t} / \mathrm{ha}$ for STS 110 . Similar application methods as initial planting (IP) was applied in the SR-1 and SR-2.

Qualified seeds were prepared by selecting qualified cane stalks derived from 8 months of sugarcane plants from stock seeds having vigor and healthy growth, and no pest and disease symptoms used as seed sources. Sugarcane stalk with two buds derived from nodes in the middle stalk of PS.862 were selected and cut using sterile sharp knifes. Selected seeds generally had $>90 \%$ grow rate, fresh, vigor, and healthy; $15-20 \mathrm{~cm}$ in length with $\pm 2 \mathrm{~cm}$ in diameter; bud and root primordia in dormant condition; and disease free. The seeds were planted in trenches prepared in two rows in overlapping position in which the buds were position laterally and then covered by media till all the seeds covered perfectly. Total seeds used per ha were $60-80$ kwintal or 10 grow buds per $m$ trench.

The cane plants were maintained from initial growth till harvest time by (1) watering applied fit with growth steps of plants; (2) soil heaping up carried out three times, first at the first fertilizing, second at 3-3.5 months after planting (MAP) and third at 4.5-5.0 MAP; (3) tiller and leaf removing, especially tillers with unoptimal growth and the old leaves aiming to improve and strengthen cane stalk growth, to suppress growth of stalk buds, to prevent stalk collapsed and plant fire. The tiller and leaf removing was carried out three times, first at 4-5 MAP, second at 7-8 MAP and third at 1-2 months before harvest time; (4) seed tatting carried out to replace fail grow of planted stalks using similar seedlings and age. The seed tatting was conducted at 3-4 MAP; (5) tiller managing carried out to control number of tillers supporting cane optimal growth. Total number of tillers maintained till harvest period were 10 tillers, when more than 10 tillers, other tillers were removed; and (6) pest and disease controlling done by applying pesticides that fit with pests and diseases attacking in suggested dosages. 


\section{Sampling design}

In the study, three planting methods tested were (1) double trench system (DTS) with $50 \mathrm{~cm}$ distance between trench and $135 \mathrm{~cm}$ distance between double trenches; (2) single trench system (STS) with $120 \mathrm{~cm}$ distance of canter to center (CTC) and (3). STS with $110 \mathrm{~cm}$ distance of CTC. The experiment was arranged in randomized complete block design (RCBD) with 6 replications. The experiment was conducted three years from 2015 to 2017 from IP to SR-1 and SR-2. Each treatment consisted ot 30 experimental plots. Each plot was $12 \times 24 \mathrm{~m}$ with $1.5 \mathrm{~m}$ distance between plot. Each plot contained 21,216 seeds for DTS 50/135; 16,300 seeds for STS 120 and 17,136 seeds for STS 110 with 1,724,424 total of seeds planted. Total experimental samples were 20 plants that were established randomly.

Variables observed in the study were (1) plant height $(\mathrm{cm}),(2)$ stalk length $(\mathrm{cm}),(3)$ stalk diameter $(\mathrm{cm})$, (4),number of nodes per plant, (5) number of productive tillers per plant (6) percentage of Brix (\%), (7) fresh stalk weight ( $\mathrm{kg} / \mathrm{stalk}),(8)$ cane yield (\%), (9) number of stalks per $\mathrm{m}$ trench and (10) sugarcane productivity $(\mathrm{t} / \mathrm{ha})$. Periodical observation was carried out to reveal growth response of cane from initial planting till harvest period. The variables were observed and measured 10 months after planting (MAP). While partial economic analysis of three planting methods tested in the study was carried out by comparing input and output variable costs, especially to establish revenue cost ratio (R/C ratio) (Hajar et al., 2019).

\section{Statistical procedures}

Quantitative data in the experiments were analyzed using analysis of variance (ANOVA). Significant differences between means were assessed by Tukey test, $p=0.05$ (Mattjik and Sumertajaya, 2006).

\section{Results and Discussion}

Based on periodical observation it was known that initial bud germination was occurred 13-17 days after planting (DAP) with 24.7 to $35.2 \%$ germination rate and 15 to $20 \mathrm{~cm}$ height of plants. The shoots continually grew and developed in the further observation. Shoots with $50-65 \mathrm{~cm}$ height and $3-5$ leaves were noted at 30 DAP. Initial tillers were recorded 25 - 30 DAP, 90\% germination rate 2 MAP with optimal number of tillers up to 14 tillers per plants recorded at 4 MAP. From 7-14 tillers noted per plants, the productive tillers were $53.4-71.2 \%$ while $28.8-46.6 \%$ of tillers were removed due to their un-qualified and un-optimal growth (Data not shown). In the harvest period, the plant height was varied from $237-423 \mathrm{~cm}$ with $161-249 \mathrm{~cm}$ stalk length, $2.4-2.7 \mathrm{~cm}$ stalk diameter, $15-24$ nodes per plant, $4.5-6.7$ productive tillers, $19.5-21.7 \%$ of Brix, $1.2-2.7 \mathrm{~kg}$ fresh stalk weight, $7.7-8.9 \%$ cane yield, $8-15$ stalks per $\mathrm{m}$ trench and $69.4-134.2 \mathrm{t} / \mathrm{ha}$ sugarcane productivity in which sugarcane growth and yield performances were significantly observed on DTS 50/135 planting method.

Different planting methods investigated in the three years of study, it was successfully revealed that the different planting methods gave significant effect on growth and yield performances of sugarcane PS.862 variety, statistically. DTS 50/135 was the most suitable planting methods applied to increase and improve sugarcane growth and plant productivity. The method stimulated optimal plant growth with 6 productive tillers, $21.7 \%$ of Brix, $1.72 \mathrm{~kg}$ fresh stalk weight, $8.86 \%$ cane yield, 14 stalks per $\mathrm{m}$ trench and $129.12 \mathrm{t} / \mathrm{ha}$ cane yield in the IP (Table 1). The highest improvement of sugarcane growth and yield performances was significantly noted in the SR-1 under the similar method. Higher results in the treatment were 6 productive tillers, 15 stalks per $\mathrm{m}$ trench and $134.2 \mathrm{t} / \mathrm{ha}$, respectively (Table 2). While in the SR-2, higher plant height up to $393 \mathrm{~cm}, 287 \mathrm{~cm}$ stalk length, $2.76 \mathrm{~cm}$ stalk diameter, 24 nodes per plant, 6.7 productive tillers, $1.62 \mathrm{~kg}$ fresh stalk weight, 13 stalks per $\mathrm{m}$ trench and $114.2 \mathrm{t} /$ ha cane productivity was recorded on DTS 50/135 (Table 3 ). While second best planting method was STS 120 . The planting method also successfully improved sugarcane growth and yield performances compared to STS 110 planting method. 
Table 1. Cane growth and yield performances under different planting methods in the initial planting

\begin{tabular}{|c|c|c|c|c|c|c|c|c|c|c|}
\hline $\begin{array}{l}\text { Planting } \\
\text { method }\end{array}$ & $\begin{array}{l}\text { Plant } \\
\text { height } \\
(\mathrm{cm})\end{array}$ & $\begin{array}{c}\text { Stalk } \\
\text { length } \\
(\mathrm{cm})\end{array}$ & $\begin{array}{c}\text { Stalk } \\
\text { diameter } \\
(\mathrm{cm})\end{array}$ & $\begin{array}{c}\text { Number } \\
\text { of nodes } \\
\text { per } \\
\text { plant }\end{array}$ & $\begin{array}{c}\text { Number of } \\
\text { productive } \\
\text { tillers per } \\
\text { plant }\end{array}$ & $\begin{array}{l}\text { Percentage } \\
\text { of Brix }(\%)\end{array}$ & $\begin{array}{c}\text { Fresh stalk } \\
\text { weight } \\
\text { (kg/stalk) }\end{array}$ & $\begin{array}{c}\text { Sugar } \\
\text { cane } \\
\text { yield } \\
(\%)\end{array}$ & $\begin{array}{c}\text { Number of } \\
\text { stalks per } \\
\text { m trench }\end{array}$ & $\begin{array}{l}\text { Sugarcane } \\
\text { productivity } \\
\text { (t/ha) }\end{array}$ \\
\hline DTS $50 / 135$ & $296.5 \mathrm{a}$ & $218.8 \mathrm{a}$ & $2.67 \mathrm{a}$ & $16.2 \mathrm{~b}$ & $6.0 \mathrm{a}$ & $21.7 \mathrm{a}$ & $1.72 \mathrm{a}$ & $8.86 \mathrm{a}$ & $14.0 \mathrm{a}$ & $129.12 \mathrm{a}$ \\
\hline STS 120 & $297.3 \mathrm{a}$ & $227.2 \mathrm{a}$ & $2.69 a$ & $18.2 \mathrm{a}$ & $5.0 \mathrm{~b}$ & $20.1 \mathrm{a}$ & $1.60 \mathrm{a}$ & $8.04 \mathrm{a}$ & $12.2 \mathrm{a}$ & $111.82 \mathrm{~b}$ \\
\hline $\begin{array}{l}\text { STS } 110 \\
\text { (control) }\end{array}$ & $236.8 \mathrm{~b}$ & $161.2 \mathrm{~b}$ & $2.62 \mathrm{a}$ & $14.8 \mathrm{~b}$ & $4.5 \mathrm{~b}$ & $19.5 \mathrm{a}$ & $1.18 \mathrm{~b}$ & $7.74 \mathrm{a}$ & $10.0 \mathrm{~b}$ & $91.78 \mathrm{c}$ \\
\hline $\begin{array}{l}\text { Coefficient } \\
\text { of variation } \\
\text { (CV) }\end{array}$ & 3.83 & 5.82 & 8.74 & 7.10 & 11.72 & 8.93 & $10.74 \mathrm{a}$ & 11.08 & 10.46 & 2.02 \\
\hline
\end{tabular}

Note: DTS 50/135 - double trench system (DTS) with $50 \mathrm{~cm}$ distance between trench and $135 \mathrm{~cm}$ distance between double trenches; (2) single trench system (STS) with $120 \mathrm{~cm}$ distance of canter to center (CTC) and (3). STS with $110 \mathrm{~cm}$ distance of CTC, Means followed by the same letter in the same column are not significantly different based on Tukey test, $p=0.05$

Table 2. Sugarcane growth and yield performances under different planting methods in SR-1

\begin{tabular}{|c|c|c|c|c|c|c|c|c|c|c|}
\hline $\begin{array}{c}\text { Planting } \\
\text { method }\end{array}$ & $\begin{array}{l}\text { Plant } \\
\text { height } \\
(\mathrm{cm})\end{array}$ & $\begin{array}{c}\text { Stalk } \\
\text { length } \\
(\mathrm{cm})\end{array}$ & $\begin{array}{c}\text { Stalk } \\
\text { diameter } \\
(\mathrm{cm})\end{array}$ & $\begin{array}{l}\text { Number } \\
\text { of nodes } \\
\text { per plant }\end{array}$ & $\begin{array}{c}\text { Number of } \\
\text { productive } \\
\text { tillers per } \\
\text { plant }\end{array}$ & $\begin{array}{l}\text { Percentage } \\
\text { of Brix (\%) }\end{array}$ & $\begin{array}{c}\text { Fresh } \\
\text { stalk } \\
\text { weight } \\
\text { (kg/stalk) }\end{array}$ & $\begin{array}{c}\text { Sugarcane } \\
\text { yield (\%) }\end{array}$ & $\begin{array}{c}\text { Number } \\
\text { of stalks } \\
\text { per m } \\
\text { trench }\end{array}$ & $\begin{array}{c}\text { Sugarcane } \\
\text { productivity } \\
(\mathrm{t} / \mathrm{ha})\end{array}$ \\
\hline DTS 50/135 & $412.0 \mathrm{a}$ & $248.0 \mathrm{a}$ & $2.76 \mathrm{a}$ & $21.0 \mathrm{a}$ & $6.0 \mathrm{a}$ & $20.9 a$ & $1.56 \mathrm{a}$ & $8.47 \mathrm{a}$ & $15.0 \mathrm{a}$ & $134.20 \mathrm{a}$ \\
\hline STS 120 & $423.0 \mathrm{a}$ & $249.0 \mathrm{a}$ & $2.70 \mathrm{a}$ & $21.0 \mathrm{a}$ & $5.5 \mathrm{a}$ & $19.9 \mathrm{~b}$ & $1.64 \mathrm{a}$ & $7.96 \mathrm{~b}$ & $12.0 \mathrm{~b}$ & $129.85 \mathrm{~b}$ \\
\hline $\begin{array}{l}\text { STS } 110 \\
\text { (control) }\end{array}$ & $374.0 \mathrm{~b}$ & $223.0 \mathrm{~b}$ & $2.72 \mathrm{a}$ & $19.0 \mathrm{~b}$ & $4.8 \mathrm{a}$ & $21.4 \mathrm{a}$ & $1.38 \mathrm{a}$ & $8.72 \mathrm{a}$ & $9.0 \mathrm{c}$ & $89.43 c$ \\
\hline $\begin{array}{l}\text { Coefficient } \\
\text { of variation } \\
\text { (CV) }\end{array}$ & 3.19 & 5.45 & 5.47 & 5.08 & 16.31 & 2.61 & 12.17 & 3.23 & 7.76 & 2.17 \\
\hline
\end{tabular}

Means followed by the same letter in the same column are not significantly different based on Tukey test, $\mathrm{p}=0.05$

Table 3. Sugarcane growth and yield performances under different planting methods in SR-2

\begin{tabular}{|c|c|c|c|c|c|c|c|c|c|c|}
\hline $\begin{array}{l}\text { Planting } \\
\text { method }\end{array}$ & $\begin{array}{l}\text { Plant } \\
\text { height } \\
(\mathrm{cm})\end{array}$ & $\begin{array}{c}\text { Stalk } \\
\text { length } \\
(\mathrm{cm})\end{array}$ & $\begin{array}{c}\text { Stalk } \\
\text { diameter } \\
(\mathrm{cm})\end{array}$ & $\begin{array}{l}\text { Number } \\
\text { of nodes } \\
\text { per plant }\end{array}$ & $\begin{array}{c}\text { Number of } \\
\text { productive } \\
\text { tillers per } \\
\text { plant }\end{array}$ & $\begin{array}{l}\text { Percentage } \\
\text { of Brix (\%) }\end{array}$ & $\begin{array}{c}\text { Fresh } \\
\text { stalk } \\
\text { weight } \\
\text { (kg/stalk) }\end{array}$ & $\begin{array}{c}\text { Sugarcane } \\
\text { yield (\%) }\end{array}$ & $\begin{array}{c}\text { Number } \\
\text { of stalks } \\
\text { per m } \\
\text { trench }\end{array}$ & $\begin{array}{c}\text { Sugarcane } \\
\text { productivity } \\
(\mathrm{t} / \mathrm{ha})\end{array}$ \\
\hline $\begin{array}{l}\text { DTS } \\
50 / 135\end{array}$ & $393.0 \mathrm{a}$ & $287.0 \mathrm{a}$ & $2.76 \mathrm{a}$ & $24.0 \mathrm{a}$ & $6.7 \mathrm{a}$ & $20.8 \mathrm{a}$ & $1.62 \mathrm{a}$ & $8.41 \mathrm{a}$ & $13.0 \mathrm{a}$ & $114.2 \mathrm{a}$ \\
\hline STS 120 & $287.0 \mathrm{c}$ & $245.0 \mathrm{~b}$ & $2.40 \mathrm{~b}$ & $21.0 \mathrm{~b}$ & $5.8 \mathrm{ab}$ & $21.5 \mathrm{a}$ & $1.45 \mathrm{~b}$ & $8.75 \mathrm{a}$ & $11.0 \mathrm{~b}$ & $98.8 \mathrm{~b}$ \\
\hline $\begin{array}{l}\text { STS } 110 \\
\text { (control) }\end{array}$ & $307.0 \mathrm{~b}$ & $247.0 \mathrm{~b}$ & $2.47 \mathrm{~b}$ & $19.0 \mathrm{~b}$ & $5.2 \mathrm{~b}$ & $21.4 \mathrm{a}$ & $1.28 \mathrm{c}$ & $8.72 \mathrm{a}$ & $8.0 \mathrm{c}$ & $69.4 \mathrm{c}$ \\
\hline $\begin{array}{l}\text { Coefficient } \\
\text { of variation } \\
\text { (CV) }\end{array}$ & 3.18 & 5.47 & 5.39 & 7.36 & 12.27 & 2.70 & 6.12 & 3.33 & 7.65 & 2.92 \\
\hline
\end{tabular}

Means followed by the same letter in the same column are not significantly different based on Tukey test, $p=0.0$

Furthermore, based on sugarcane productivity in each year cultivation, there were significant cane productivity improvement up to $40.8,51.1$ and $64.6 \%$, respectively in IP, SR-1 and SR-2 affected by application of DTS 50/135 (Table 4). Lower improvement was noted on STS 120 compared to STS 110. Whereas based on cane productivity pattern from IP to SR-2, application of DTS 50/135 and STS 120 improved sugarcane productivity in SR-1 and reduced thereafter in the SR-2. Results of the study carried out from 2015 to 2017 were successfully revealed that DTS 50/135 was the most suitable planting method applied to improved growth and yield performances on PS.862 variety. High quality and productivivy of the sugarcane variety could be maintained up to SR-1 and declined with almost similar results in SR-2 compared to IP. The results also gave evident that sugarcane planting cyclus was only maintained for three years from IP to SR-2 and the sugarcane cultivation shall be initiated from the IP again. 
Table 4. Percentage of sugarcane productivity improvement in IP, SR-1 and SR-2 (\%)

\begin{tabular}{|l|c|c|c|}
\hline \multirow{2}{*}{ Planting method } & \multicolumn{3}{|c|}{ Improvement of sugarcane productivity on IP to SR-1 and SR-2 (\%) } \\
\cline { 2 - 4 } & IP & SR-1 & SR-2 \\
\hline DTS 50/135 & 40.8 & 51.1 & 64.6 \\
\hline STS 120 & 21.8 & 45.2 & 42.4 \\
\hline STS 110 (control) & 0 & 0 & 0 \\
\hline
\end{tabular}

Sugarcane farming economic analysis carried out it was also revealed that different planting methods gave significant different revenue-cost (R/C) ratios. Application of DTS 50/135 and STS 120 stimulated higher R/C than STS 110 in IP, SR-1 and SR-2. The both treatments had R/C ratio from 1.16 and 1.18 in IP than increased up to 1.94 and 1.99 in CR-1 and reduced thereafter down to 1.53 and 1.52, respectively (Table 5). Improvement of R/C ratio on IP was only $11.5 \%$ on DTS 50/135 and $13.5 \%$ on STS 120 compared to STS 110, however significant enhancement was noted on CR-1 with 18.3 and $21.3 \%$ then reduced with 10.1 and $9.4 \%$, respectively (Table 5). Though the DTS $50 / 135$ had lower R/C ratio than STS 120 , total sugarcane productivity of DTS 50/135 was higher than STS 120. Results of the study indicated that application of DTS 50/135 and STS 120 improved farmer profit on sugarcane farming. The results can also make sure to cane farmers in applying the DTS 50/135 or STS 120 in increasing their profits.

Tabel 5. Partial farming economic analysis of sugarcane under different planting methods of DTS 50/135, STS 120 and STS 110 for PS.862 variety

\begin{tabular}{|c|c|c|c|c|c|c|c|c|c|c|c|c|}
\hline \multirow{2}{*}{$\begin{array}{l}\text { Planting } \\
\text { method }\end{array}$} & \multicolumn{3}{|c|}{$\begin{array}{l}\text { Total farming economic cost } \\
\left(\text { Rp.000,-/ } \mathrm{ha}^{-1}\right)\end{array}$} & \multicolumn{3}{|c|}{$\begin{array}{c}\text { Income } \\
\left(\text { Rp.000,-/ha }{ }^{-1}\right)\end{array}$} & \multicolumn{3}{|c|}{$\begin{array}{c}\text { Profit } \\
\left(\text { Rp.000,-/ha }{ }^{-1}\right)\end{array}$} & \multicolumn{3}{|c|}{$\begin{array}{l}\mathrm{R} / \mathrm{C} \\
\text { ratio }\end{array}$} \\
\hline & PC & SR-1 & SR-2 & IP & SR-1 & SR-2 & IP & SR-1 & SR-2 & IP & SR-1 & SR-2 \\
\hline $\begin{array}{l}\text { DTS } \\
50 / 135\end{array}$ & 55,642 & 44,278 & 44,622 & 64,563 & 85,894 & 68,400 & 8,920 & 41,616 & 23,778 & 1.16 & 1.94 & 1.53 \\
\hline STS 120 & 47,284 & 41,742 & 39,273 & 55,905 & 82,995 & 59,880 & 8,621 & 41,253 & 20,607 & 1.18 & 1.99 & 1.52 \\
\hline STS 110 & 22,820 & 15,464 & 15,464 & 23,660 & 25,420 & 21,514 & 840 & 9,956 & 6,050 & 1.04 & 1.64 & 1.39 \\
\hline
\end{tabular}

Entirely from the study, it was successfully revealed that application of different planting methods from the existing planting method usually applid by farmers in Gedangdowo village, Jepon Subdistrict, Blora District, Central Java-Indonesia gave significant effect on growth and yield of PS.862 variety and farmer profits. From the study, it was importantly proved that DTS 50/135 was the best planting method significantly increased sugarcane productivity up to $129.12 \mathrm{t} /$ ha in IP, $134.2 \mathrm{t} / \mathrm{ha}$ in SR-1 and $114.2 \mathrm{t} /$ ha in SR-2 primarily due to higher productive tillers and number of stalks per $\mathrm{m}$ trench. Other studies revealed that the sugarcane yield of $87 \mathrm{~A} 298$ variety in conventional planting method was $128.7 \mathrm{t} / \mathrm{ha}$ and increased up to $149.5 \mathrm{t} / \mathrm{ha}$ using trench method (spacing-30 cm width x $30 \mathrm{~cm}$ depth, 12 settlings with paired systems of planting) mainly affected by number of millable sugarcanes and number of shoots/ha (Gulati et al., 2015), a double row CTC $50 / 170 \mathrm{~cm}+$ double seeds planting arrangement produced the highest sugarcane productivity of Bululawang variety and sugar yield up to $191.02 \mathrm{t} / \mathrm{ha}$ and $15.33 \mathrm{t} / \mathrm{ha}$, respectively (Djumali et al., 2016), the cane yield of CoS-8436 variety in conventional planting system produced $77.53 \mathrm{t} /$ ha and increased up to 82.50 tons/ha using paired row trench plantation technique primarily influenced by number of millable sugarcanes, sugarcane length and weight (Prem et al., 2017), the maximum stripped sugarcane yields of $154.36 \mathrm{t} / \mathrm{ha}$ and $130.28 \mathrm{t} / \mathrm{ha}$ of CPF-247 variety mainly affected by number of millable sugarcanes and plant height in initial plant and ratoon crop, respectively were obtained from sugarcane planted at $120 \mathrm{~cm}$ trench planting both as sole as well as lentil intercropped (Nadeem et al., 2020). Based on the results of the study and other researches it was clearly proved that application of double trench planting system that increased in number of productive tillers and millable sugarcanes successfully increased sugarcane productivity.

Application of new planting methods for improving sugarcane growth and yield performances that lead to increasing profits can give high effect to farmers in adopting and applying the proved planting method in their sugarcane farming activities. Improvement of sugarcane productivity due to applying the new planting 
methods were varied from low to high percentage productivity. In the study, application of DTS 50/135 planting method enhanced sugarcane productivity of PS.862 variety up to 40.8, 51.1 and 64.6\%, respectively in IP, SR-1 and SR-2. In other results, percentage of sugarcane productivity improvement was noted up to 16.2\% for 87A298 variety (Gulati et al., 2015), 12.3\% for Bululawang variety (Djumali et al., 2016), 6.4\% for CoS-8436 variety (Prem et al., 2017), 60.6\% for CPF-247 variety. The percentage of improvement values gave evident that the new planting methods had high potential applied for further sugarcane farming activities by farmers.

High preferences of farmers to continue on applying new techniques for their sugarcane farmings are significantly affected by the existence of as high as profits they get in their final farming activities. From the previous studies, it was successfully revealed that application of new planting methods, especially paired or double trench system, increased varied-R/C ratio from $4-30 \%$. Djumali et al. (2016) found that double row CTC 50/170 planting method induced $\mathrm{R} / \mathrm{C}$ ratio up to 1.62 with $13.3 \%$ improvement compared to STS 110 in SR-1, the double rows cropping system led to additional revenue of $\mathrm{Rp} 4.67$ million per hectare with marginal benefit cost ratio (MBCR) value of 1.79 with $4.4 \%$ improvement compared to conventional system (Hutahaean and Ernawanto, 2015), paired row trench plantation system had 2.70 benefit cost ratio (BCR) with 17.4\% higher than conventional planting method (Prem et al., 2017), $120 \mathrm{~cm}$ trench planting system stimulated BCR up to 1.98 with $29.4 \%$ increasing compared to conventional one (Nadeem et al., 2020). In the study, R/C ratio of DTS 50/135 planting system was 1.16 in IP than increased up to 1.94 in SR-1 and reduced thereafter down to 1.53 in SR-2. Improvement of R/C ratio on IP was only $11.5 \%$ on DTS 50/135 and significant enhancement up to $18.3 \%$ was noted on SR-1 then reduced down to $10.1 \%$ on SR-2. However, the $\mathrm{R} / \mathrm{C}$ ratio and improvement values were lower than STS 120 planting system in IP and SR-1.

\section{Conclusions}

Finally it can be concluded that improvement of sugarcane growth and yield performances via application of different planting methods and their partial economic analysis was successfully revealed in the study. DTS 50/135 was the most appropriate planting method to improve cane growth and yield performances of PS.862 variety and its economic analysis. The higher sugarcane growth and yield performances were primarily induced by number of productive tillers and number of stalks per $\mathrm{m}$ trench. Percentage of cane productivity was increased up to $40.8 \%$ in IP, $51.1 \%$ in SR-1 and $64.6 \%$ in SR-2. Higher results were also indicated by STS 120 than the STS 110. Higher R/C ratio was stimulated by STS 120 and DTS 50/135 than STS 110. Increasing R/C ratio from the planting method and DTS 50/135 was varied from $9.4-21.3 \%$ in the IP, SR-1 and SR-2 compared to STS 110 as planting method.

\section{Authors' Contributions}

B.H. contributed on research planning, executing till finishing and preparing research report. $\mathrm{H}$ and F.D.A took part in helping the research planning and data analyzing. S.M. and R.H.P. were involved in observing and taking research data. B.W. has important roles in rechecking, re-analyzing and fixing data performances; guiding authors in writing, reviewing and revising manuscript till manuscript ready for international journal submission; helping authors in selecting journal target, formatting, preparing supplement data for submission, helping in manuscript revision till proofreading.

All authors read and approved the final manuscript. 
Winarto B et al. (2021). Not Sci Biol 13(2):10856

\section{Acknowledgements}

We express our gratitude to the Central Java Assessment Institute for Agricultural Technology (CJAIAT) for funding the research activities under 2014 to 2017 CJAIAT Research Grand.

\section{Conflict of Interests}

The authors declare that there are no conflicts of interest related to this article.

\section{References}

Bikila M, Dechassa N, Alemayehu N (2014). Effects of pre-cutting nitrogen application rate and time on seed cane quality of sugarcane (Saccharum officinarum L.) crop at Finchaa sugar estate. Advances in Crop Sciences and Technology 2:152. https://doi.org/10.4172/2329-8863.1000152

Blora Statistic (2015). Blora in figures 2016. BPS Catalog: 1102001.3316, BPS-Statistics Blora Regency, pp 426.

Blora Statistic (2016). Blora in figures 2016. BPS Catalog: 33160.1605, BPS-Statistics Blora Regency, pp 391.

Blora Statistic (2017). Blora in figures 2017. BPS Catalog: 1102001.3316, BPS-Statistics Blora Regency, pp 383.

Bokhtiar SM, Roksana S, Moslehuddin AZM (2015). Soil fertility and productivity of sugarcane influenced by enriched pressmud compost with chemical fertilizers. SAARC Journal of Agriculture 13(2):183-197.

Casaroli D, Júnior JA, Evangelista AWP (2019). Quantitative and qualitative analysis of sugarcane productivity in function of air temperature and water stress. Comunicata Scientiae 10(1):203-212.

Cholid M (2013). Improvement of sugarcane productivity and yield via source-sink approach. Info Teknik Perkebunan 5(12):46.

De Silva AGSD, Sanotharan N, Senevirathna CJ, Perera SK (2019). Analysis of the factors affecting farmers' perception toward the sugarcane cultivation of small-scale farmers in Monaragala District of Sri Lanka. International Journal of Advances and Research 4(1):35-38.

Diana NE, Supriyadi, Djumali (2016). Growth, productivity, and sugar content of plant cane on several fertilizer pockets. Jurnal Ilmu Pertanian Indonesia 21(3):159-166.

Directorate General of Estate (2020a, b, c). Sugarcane area by province in Indonesia, 2016-2020. [Online]. Website: https://www.pertanian.go.id/home/:show=page\&act=view\&id=61

Djumali, Khuluq AD, Mulyaningsih S (2016). Sugarcane growth and productivity on several planting arrangement packages in upland area. Jurnal Agronomi Indonesia 44(2):211-219.

Gulati JML, Sunmarg C, Jitendra Behra K, Jena SN, Lenka S (2015). Effect of planting methods on growth pattern and productivity of sugarcane varieties. Indian Journal of Agricultural Research 49(3):222-228. https://doi.org/10.5958/0976-058X.2015.00034.7

Hajar I, Susanti A, Prasetjono H (2019). Sugarcane agribusiness economical analysis: Case study at Munung village, Jatikalen subdistrict, Nganjuk District-East Java. Agrosaintifika: Jurnal Ilmu Pertanian 1(2):51-58.

Hendayana R, Sudana W, Alihamsyah T, Yusron M, Supriyatna A, Erythrina (2014). Book guide for mentoring and guarding in acceleration of sugarcane integrated crop management. Indonesian Agency for Agriculture Research and Development. Agriculture Ministry, pp 56.

Hutahaean L, Ernawanto QD (2015). The feasibility of sugar cane farming with double row cropping system in East Java and Central Java. Jurnal Pengkajian dan Pengembangan Teknologi Pertanian 18(2):157-167.

Indonesian Trading Ministry (2020). Low sugarcane productivity stimulate high price of sugar nationally. http://ewscb.kemendag.go.id

Kadarwati TF (2020). Effect of different levels of potassium on the growth and yield of sugarcane ratoon in inceptisols.

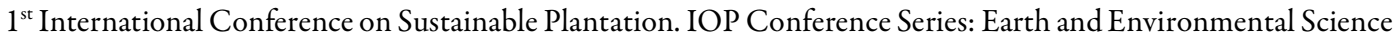
418:1-11. https://doi.org/10.1088/1755-1315/418/1/012066

Lemos dos Santos R, Freire FJ, Almeida de Oliveira FC, Neto DES, Amaral de Medeiros MRF (2018). Productivity and technological quality of sugarcane under fertilization of nitrogen and molybdenum. Journal Soil Sciences of Plant Nutrition 18(4):1002-1020. 
Majid HR (2014). Effect of planting material and row spacing on sugarcane yield and quality. AL - Muthanna Journal of Agricultural Sciences 2(1):1-11.

Mattjik AA, Sumertajaya IS (2006). Experimental design with sas and minitab application. IPB Press. Bogor, pp 276.

Mishra K (2019). Evaluation of bud chip method for enhancing yield and economics of sugarcane. International Journal of Chemical Studies 7(3):1726-1729.

Muttaqin L, Taryono, Kastono D, Sulistyono W (2016). Effect of intra-row spacing on early growth of bud chip seedlings of five sugarcane (Saccharum officinarum L.) clones in alfisol dry land. Vegetalika 5(2):49-61.

Nadeem M, Tanveer A, Sandhu A, Javed S, Safdar ME, Ibrahim M, ... Arshad U (2020). Agronomic and economic evaluation of autumn planted sugarcane under different planting patterns with lentil intercropping. Agronomy 10(644):1-24. https://doi.org/10.3390/agronomy10050644

Ngatinem A, Yulianto, Rusdi N (2019). The Effect of planting distance to sugarcane (Sacharum officinarum L.) plants growing using single-bud seed. International Journal of Scientific and Techology Research 8(2):10-14.

Pokharel D, Uprety R, Mehata S, Shrestha HK, Panday D (2019). Dynamics and economic analysis of sugarcane production in eastern plains of nepal. Current Agricultural Research Journal 7(2):201-212.

Prem G, Ramesh K, Singh VD, Kumar A, Choudhary R, Ahmad A (2017). Effect of planting methods on cane yield, water productivity and economics of spring planted sugarcane (Saccharum officinarum L.) in Ambala (Haryana). International Journal of Agricultural Engineering $10(1): 186-190$. https://doi.org/10.15740/HAS/IJAE/10.1/186-190

Singh P, Singh SN, Tiwari AK, Pathak SK, Singh AK, Srivastava S, Mohan N (2019). Integration of sugarcane production technologies for enhanced cane and sugar productivity targeting to increase farmers' income: strategies and prospects. 3 Biotech 9(48):1-15. https://doi.org/10.1007/s13205-019-1568-0

Society Relation Department (2020). Maintain stock and price of main food, Indonesian Trading Ministry did market operation at Jakarta. Society Relation Department. Indonesian Trading Ministry, pp 2.

Srivastava AK, Rai MK (2012). Sugarcane production: Impact of climate change and its mitigation. Biodiversitas 13(4):214-227. https://doi.org/10.13057/biodiv/d130408

Sudarto YG, Buludan, Utami SK (2020). Study of some cane varieties on dry land agroecosystems in Dompu district NTB. Crop Agro 13(1):10-21.

Tando E (2017). Review: Improvement sugarcane productivity (Saccarum officinarum L.) on dry land using organic materials and synthetic soil moisture. Jurnal Biotropika 5(3):90-97.

Zaky Y, Pambudy R, Harianto (2019). Sugarcane agribusiness efficiency analysis on cooperator and non-cooperator farmer at Blora district-Central Java. Agribusiness Forum 9(1):85-106.

Zuraina WK, Pudjianto E, Undin A, Damarjati SN, Magdalena E (2018). Tree crop estate statistics of Indonesia 2017 2019: Sugarcane. Secretariate of Directorate General of Estate Crops. Directorate General of Estate Crops. Ministry of Agriculture, pp 52.
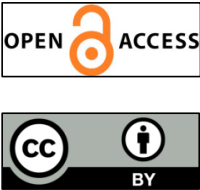

The journal offers free, immediate, and unrestricted access to peer-reviewed research and scholarly work. Users are allowed to read, download, copy, distribute, print, search, or link to the full texts of the articles, or use them for any other lawful purpose, without asking prior permission from the publisher or the author.

License - Articles published in Notulae Scientia Biologicae are Open-Access, distributed under the terms and conditions of the Creative Commons Attribution (CC BY 4.0) License.

(c) Articles by the authors; SHST, Cluj-Napoca, Romania. The journal allows the author(s) to hold the copyright/to retain publishing rights without restriction. 